Int. J. Dev. Biol. 50: 183-191 (2006)

doi: $10.1387 /$ ijdb.052077sc

\title{
Effects of microgravity on cell cytoskeleton and embryogenesis
}

\author{
SUSAN J. CRAWFORD-YOUNG* \\ Department of Electrical and Computer Engineering, University of Manitoba, Winnipeg, Manitoba, Canada
}

\begin{abstract}
The aim of this review is to compile, summarize and discuss the effects of microgravity on embryos, cell structure and function that have been demonstrated from data obtained during experiments performed in space or in altered gravity induced by clinostats. In cells and tissues cellular structure and genetic expression may be changed in microgravity and this has a variety of effects on embryogenesis which include death of the embryo, failure of neural tube closure, or final deformities to the overall morphology of the newborn or hatchling. Many species and protocols have been used for microgravity space experiments making it difficult to compare results. Experiments on the ways in which embryonic development and cell interactions occur in microgravity could also be performed. Experiments that have been done with cells in microgravity show changes in morphology, cytoskeleton and function. Changes in cytoskeleton have been noted and studies on microtubules in gravity have shown that they are gravity sensitive. Further study of basic chemical reactions that occur in cells should be done to shed some light on the underling processes leading to the changes that are observed in cells and embryos in microgravity.
\end{abstract}

KEY WORDS: embryo, development, cell, cytoskeleton, microgravity

\section{Introduction}

The structure of cells is altered in microgravity with differences in the cytoskeleton, apoptosis rate and cellular responses to the environment (Sakar et al., 1999; Uva et al., 2002; Sundareasan et al., 2001). Cytoskeletal components such as microtubules are changed in microgravity and this is presumed to explain the effect of microgravity on cells (Papaset et al., 2000). Despite the altered cell morphology and functions observed in many of the experiments performed in microgravity, embryos of some animal species can still develop into living organisms that are able to reproduce. However, the microgravity-induced pathology of embryo development has not been clearly defined in mammals nor in humans, nor is it fully understood. Findings on the pathology of development in altered gravity have often been contradictory. In order to explain the cellular mechanisms involved in the malformations of embryos that may be induced in microgravity, many more studies of cell development during embryogenesis need to be conducted. We may need to look further to the fields of teratology and developmental pathology in order to examine cellular processes in embryonic development in microgravity with the aim of defining and standardizing the abnormal data. Embryonic processes such as cell sorting, intercalation and embryonic waves need to be studied in microgravity to see what changes occur and why. Studies in artificially produced microgravity in clinostats should be compares with the microgravity of space and artificially produced $1 \mathrm{G}$ in space should be compared to $1 \mathrm{G}$ earth normal gravity controls.

\section{Embryos in microgravity}

There have been many studies done on embryos in microgravity and a variety of species have been used (Fritzsch and Bruce, 1995; Gaboyard et al., 2002; Gualandris-Parisot et al., 2001; Horneck, 1999; Ijiri, 1995; Kojima et al., 2000; Neff et al., 1993; Orban et al., 1999; Schatten et al., 1999). Comparing variations in embryo development over a broad range of species can be difficult. Each species has differing rates of development and has different sensitivities to perturbations in their environment. There have been difficulties studying development in microgravity in space when using the whole developmental period from fertilization to hatching.

\section{Animal dysmorphologies}

A successful mating of vertebrate animals was carried out in 1994 using specially chosen Medaka fish (ljiri, 1995). The fish were chosen from a strain that was resistant to looping, a swimming

Abbreviations used in this paper: $\mathrm{MF}$, microfilament; IF, intermediate filament; MT, microtubule.

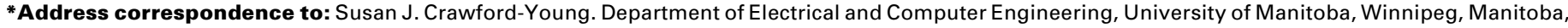
R3T 5V6, Canada. Fax +1-204-787-2080. e-mail: mudworks@cici.mb.ca
} 
behavior in microgravity. The fish had some difficulties mating in space but managed to do so and produce live offspring that looked and acted normally (ljiri, 1995).

Organisms on earth have developed in $1 \mathrm{G}$ gravity and are adapted to it. Changes in gravity from $1 \mathrm{G}$ earth normal will likely have effect on embryogenesis which have been suggested to be an additional stress on the developing organism (Ubbels, 1997; Horneck, 1999). "It has been noted that in microgravity the morphological variation is subject to drastic increase" (Dorfman and Cherdantsev, 1977).

There have been experiments carried out using Drosophila melanogasterwith conflicting results. Experiments with Drosophila during the IML-2 14.5 day space mission used several thousand eggs that hatched and developed in microgravity. The recovered embryos and flies were normal (Marco et al., 1996). In other experiments there appeared to be a higher death rate of developing flies in microgravity ( $\mathrm{Li}$ and Wang, 1992; Vernós et al., 1989; Horneck, 1999). Some of the developmental problems observed in the Drosophilawere attributed to the combination of microgravity and radiation as stressors on the developing embryo. Horneck separated the effects of radiation and microgravity and did notice an effect due to microgravity alone (Horneck, 1999).

\section{Mammals}

Deformities in mammalian embryos in microgravity have been noted:

"Fritzsch and Bruce (1995) reported that utricular and saccular axons of microgravity-exposed [rat] fetuses were largely unbranched generally ending in growth cones, whereas corresponding axons in controls showed elaborated branching. In contrast, facial sensory neurons of microgravity-exposed fetuses had exuberant branches to the utricle that were virtually absent in the controls. " (Ronca and Alberts, 2000)

Experiments have been done on rats in microgravity but, due to a lack of standardization, it is difficult to compare results (Ronca, 2003). Rats were allowed to mate in a Cosmos 1129 biosatellite experiment and the females failed to become pregnant, although fertilization had occurred (Serova et al., 1982). Development of mice in microgravity has not been successful to date when they were exposed to microgravity throughout the whole developmental period: Kojima et al. (2000) noted that the pre-implantation embryos were resorbed. A flight of the space shuttle Columbia (STS-80) had 49 mice embryos onboard. None of the two cell stage embryos showed any sign of development and they all died (Shenker and Forkheim, 1998).

Human pregnancy is counter indicated by NASA with microgravity listed as one of the factors. The reasons for this are that microgravity "May have impact on in utero embryonic development and reproductive physiology in both males and females as evidenced by animal studies" (Jennings and Santy, 1989).

\section{Amphibians}

The physical processes involved in development are an important aspect of embryogenesis. Amphibian egg orientation in gravity is important to their survival. They are normally orientated yolk down and undergo cortical rotation of 30 degrees during development. Eggs that are rotated greater than
175 degrees from perpendicular show abnormal development (Neff et al., 1984). In an experiment by Flint et al., (1990) from our lab used hollow glass spheres half filled with glycerol $(\mathrm{d}=1.25 \mathrm{~g} / \mathrm{cm} 3)$ and half filled with automotive gear oil $(\mathrm{d}=0.8 \mathrm{~g} /$ $\mathrm{cm} 3$ ) to simulate an amphibian egg structure. When the glass spheres were inverted the dense automotive gear oil flowed downward through the glycerol in an axisymetric inverted fountain rather than sloshing, suggesting that in an inverted amphibian egg the dense yolk would flow downward and cause dysmorphologies to occur in the developing animal. Sloshing motion may be required to break the cylindrical symmetry of the fertilized egg.

Experiments on amphibians in microgravity have been conducted with some evidence of malformations occurring due to microgravity.

\section{Xenopus laevis - clawed toad}

The development of early stage Xenopus embryos was studied in experiments conducted by Neff et al. (1993) in which a clinostat was used to simulate the effects of microgravity. There were changes observed at all stages of development: 1) in the early (four cell stage) embryo, cell divisions were oriented more towards the vegetal pole; 2) the blastocoel roof was thickened and in a more central position; 3 ) at the early gastrula stage, the blastopore was positioned more towards the animal pole and was deeper. The resulting hatching stage embryo had a large head, large eyes and an arched back (Neff et al., 1993) (somewhat similar to the arched back observed after compression of early gastrula axolotl embryos: Björklund et al., 1991). The larger head size could be due to a neural tube or neural plate defect, perhaps due to an altered ectoderm contraction wave (Niewkoop et al., 1996; Gordon, 1999) and it is likely that the eyes were proportionately of a larger size because the head was larger.

Current experiments in rotating wall vessels done by undergrad students at the University of North lowa show some interesting results. There is altered morphology in the head cartilage of frogs and neural crest cells show more movement in simulated microgravity (Weins and Olson, 2005).

In early embryo experiments with a clinostat by Dorfman and Cherdantsev, changes in the distribution of yolk granuals and "the dorsal blastopore lip acquires a plump shape arising as a result of a lag between entering the cells into the dorsal blastopore margin and recruiting them into the archenteron roof"(Dorfman and Cherdantsev, 1977). Later in development problems with neural tube closure were noted (Dorfman and Cherdantsev, 1977).

\section{Pleurodeles waltl - urodele amphibian - salamander}

In space experiments performed in microgravity, salamanders (Pleurodeles walt) were shown to have problems with neural tube closure in the head or cephalic region (Gualandris-Parisot et al., 2001). Eighty-one percent of the embryos had this neural tube defect and forty percent of the animals had microcephaly at the early tailbud stage. In a $1 \mathrm{G}$ centrifuge, only 4.5 percent of the embryos showed this defect. At the end of neurulation some embryos had lost neural ectoderm cells as they became detached during development. In space microgravity more neural tube closure and cell loss problems occur in the cephalic 
region. This will have a detrimental effect on the salamanders during and after development as this region is important to the development of neural crest cells as well as the developing brain.

\section{Possible mechanisms involved in neural tube problems}

The lack of closure of the neural tube in the cephalic region could be explained by the changes in cell shape induced by altered gravity. Because of disorganized microtubules, the shape of the neural cells in the developing neural tube may have been slightly altered (Uva et al., 2002). Since there are more cells in the cephalic region and the cells must undergo morphological changes to be wedge-shaped in the furrow of the bend in the neural plate a situation might arise where the neural tube cannot bend enough (Sausedo et al., 1997). Also, lamellipodiae must grow out of the closing neural plate to complete the joining of the two sides of the plate to form the neural tube. Lamellipodiae may have trouble forming in microgravity and this could potentially have an effect in creating the dysmorphologies. Lamellipodiae require actin, mi- crofilaments and microtubules to form correctly (Salamon et al., 2002). Cells became detached from the neural plate in some of the embryos and this may denote a problem with cell adhesion in microgravity (Ingber, 1999). It has been shown that the embryonic ectodermal cells of amphibians grown in microgravity do not undergo as much apoptosis as the cells do in 1G (Komazaki, 2004). Apoptosis of cells at the top of the neural plate is a process that must occur for normal development. In the absence of apoptosis of these cells, an improper closure of the neural tube may occur (Copp et al., 2003).

Another important factor in neural tube closure is calcium. Sufficient calcium needs to be present in order for neural tube closure to work (Ferreira and Hilfer 1993; Lawson et al., 2001). In space it has been shown that calcium washes out of adult newt's bodies (Besova et al., 1992). There is a change in calcium concentration in embryonic chick brain cells in microgravity (Shen et al., 1998) and there is an overall lessening of calcium in the body in microgravity (Schatten et al., 1999). Calcium utilization in developing quail embryos in microgravity was measured by

TABLE 1

\section{CHANGES IN CELLS IN MICROGRAVITY}

\begin{tabular}{|c|c|c|c|c|c|}
\hline Species & Type of cell & Microgravity conditions & Exposure time & Changes in cells compared to controls & Reference \\
\hline Chicken & Osteoblast & Space & 3 days & Reduced cell numbers: $1 / 8$ of total cells & Kacena et al., 2004 \\
\hline Human & OsteoblastROS 17/2.8 & Simulated - in clinostat & $\begin{array}{l}1 \text { day } \\
3 \text { days }\end{array}$ & $\begin{array}{l}\text { Cytoskeleton altered, leading to cell death } \\
\text { Cytoskeleton reorganized:Cells started growing }\end{array}$ & Sakar et al., 1999 \\
\hline Mouse & Bone marrow stem cells & Simulated - in clinostat & $\begin{array}{l}2 \text { days } \\
2.25 \text { days }\end{array}$ & $\begin{array}{l}\text { Engraftable stem cells } \\
\text { Reduced cell numbers } \\
\text { Reduced engraftability } \\
\text { Partial regrowth }\end{array}$ & Colvin et al., 2002 \\
\hline Human & $\begin{array}{l}\text { Bone marrow blood } \\
\text { progenitor BM CD344 }\end{array}$ & Simulated - in clinostat & $\begin{array}{l}2-3 \text { days } \\
14-18 \text { days }\end{array}$ & $\begin{array}{l}\text { Decreased directed migration } \\
\text { Decreased F-actin + altered cytoskeleton } \\
\text { Altered differentiation } \\
\text { More erythroid cell types }\end{array}$ & Plett et al., 2004 \\
\hline Human & T lymphocyte & Space & 4 hours & Microtubules disorganizedlncrease apoptosis $2 x$ & Lewis et al., 1998 \\
\hline Human & Tlymphocyte & Simulated - in clinostat & $\begin{array}{l}2 \text { days } \\
3 \text { days }\end{array}$ & $\begin{array}{l}\text { Locomotion diminished } \\
\text { Locomotion at } 14 \%\end{array}$ & Sundareasan etal., 2002 \\
\hline FrogXenopus & Muscel myocytes & $\begin{array}{l}\text { Simulated - in clinostat } \\
\text { Space }\end{array}$ & $\begin{array}{l}9.5 \text { days } \\
9.5 \text { days }\end{array}$ & $\begin{array}{l}\text { Change in actin filaments } \\
\text { Change in tylcholine receptors }\end{array}$ & Gruener et al., 1994 \\
\hline Rat & Glial tumor C6 & Simulated - in clinostat & 20 hours & $\begin{array}{l}\text { Disoriented MT, IF, MF } \\
\text { Cell shape change } \\
\text { Zero cell division and apoptosis increase } \\
\text { DNA fragmentation } \\
\text { Altered chromatin } \\
\text { Recovery of MT } \\
\text { Recovery of nucleus } \\
\text { Cell shape altered } \\
\text { Reduced cell division }\end{array}$ & Uva et al., 2002 \\
\hline Human & breast cancer MCF-7 & Space & $\begin{array}{l}1.5 \text { hours } \\
2 \text { days }\end{array}$ & $\begin{array}{l}\text { Disoriented MT, MF organized } \\
\text { Cell rounding } \\
\text { Looser cytokeratin structure } \\
\text { Mitosis is prolonged } \\
\text { Chromatin less dense }\end{array}$ & Vassy et al., 2003 \\
\hline Human & Colon Tumor & Simulated - in clinostat & 3 days & Genetic mutation & Han et al., 1999 \\
\hline Human & Thyroid follicular cancer & Simulated - in clinostat & $\begin{array}{l}1 \text { day } \\
2 \text { days } \\
3 \text { days }\end{array}$ & Increased apoptosis & Grimm et al., 2002 \\
\hline Mice & Erythroid & Simulated - in clinostat & 3 days & $\begin{array}{l}\text { Cells grew more slowly, } \\
\text { Apoptosis was the same, } \\
\text { Per cell Glucose consumption doubled } \\
\text { Differentiation was lower }\end{array}$ & Sytowski and Davis 2001 \\
\hline Human & Skin NHEK & Simulated - in clinostat & 5 days & $\begin{array}{l}\text { Increase in cell numbers } \\
\text { Greater epithelial thickness } \\
\text { Enlarged nucleus }\end{array}$ & Doolin et al., 1999 \\
\hline Human & Epithelial cancer A431 & $\begin{array}{l}\text { Simulated - in clinostat } \\
\text { and in Space }\end{array}$ & $7 \mathrm{~min}$. & $\begin{array}{l}\text { Cell roundingc-fos, c-jun expression reduced } \\
\text { F-actin in cells increased }\end{array}$ & Boonstra 1999 \\
\hline Newt & embryo ectoderm & Simulated - in clinostat & 1 day & Suppressed apoptosis & Knomazaki 2004 \\
\hline Rat pup & Utricular hair & Space & $\begin{array}{l}1 \text { day } \\
3 \text { days }\end{array}$ & $\begin{array}{l}\text { Cytoskeleton disturbed - } \\
\text { loss of cell phenotype }\end{array}$ & Gaboyard et al., 2002 \\
\hline
\end{tabular}

MT, microtubules; IF, intermediate filaments; MF, microfilaments. 
Orban (1999) results showed that the calcium utilization was impaired by $12.6 \%$. Therefore, do embryos have a lower amount of calcium in their cells and are embryonic calcium waves affected (Gilland et al., 1999; Webb and Miller, 2003)?

Actin is also important in the neural tube during closure all along the surface of the closing neural plate (Zolessi and Arruti, 2001) but actin expression was changed in many cells in microgravity (Gruener etal., 1994; Plett etal., 2004; Boonstra, 1999). The cephalic region, because it is a larger surface area, could be more susceptible to any of these factors.

Nonrandom cell division must occur in the closing neural plate for it to form normally as a majority of the cell divisions must occur within a specific timeframe or with a specific orientation in chicken. Approximately $50 \%$ of the mitotic spindles in the neuroepithelium have a rostrocaudal orientation and $70 \%$ approximately of the epidermal ectoderm has either a rostrocaudal or mediolateral orientation of the spindle. Any other combination of orientations leads to embryo death and dysmorphology (Sausedo et al., 1997; Maurus and Kuhl, 2004; Gong et al., 2004). Aligning cell division this way in microgravity may be difficult if the microtubules of mitotic spindles are affected by the lack of gravity.

\section{Questions about embryo development processes}

There are many questions to be answered about embryogenesis in microgravity. They need to be investigated before a more complete picture of the process can be assembled. Does microgravity change embryonic waves including the activation wave, waves of cytokinesis and differentiation waves? Are differentiation waves (Gordon, 1999; Björklund and Gordon, 1994) altered because cell cytoskeleton structure is changed?

Cell sorting of artificially mixed embryo cells is a process that causes cells to separate into groups according to their surface tension (Foty et al., 1996). The experiment is generally performed with dissociated embryonic cells from specific tissues that are mixed and clumped together. Cells of differing types have different surface tensions and will sort so that the cells with greater surface tension are on the inside of a tissue and those with less surface tension are on the outside. An example of this is limb bud on the inside and epithelial cells on the outside of a group of cells (Foty et al., 1996; Gordon et al., 1972, 1975). Is there a change in the surface tension and cell adhesion in embryo cells in microgravity?

Investigations of cell sorting could be done in altered gravity. Actual microscopic morphology of tissue as in Fritzsch and Bruce (1995) should be studied. When mouse brain develops, cells migrate throughout the brain area to form six layers (Marin and Rubenstein, 2003). If cell migration movements are altered in a developing animal the heart and other structures formed by the somites will not develop, causing early embryonic death (Bergwerff et al., 1997; Hutson et al., 2003). As there have been no births of mammals in space (Tou et al., 2002; Ronca, 2003) early embryonic death could be a direct result of microgravity. An overview of cell response to microgravity might reveal whether this is a plausible idea.

\section{Cells in microgravity}

Cells rely on microtubules for their structure, the transport of organelles and for the process of cell division. Adhesion sites on the cell surface also incorporate microtubules and actin into their structure (Ingber, 2003b), a process that may influence cell-cell interactions. Intermediate filaments also determine cell shape and support the other cytoskeleton structures of microtubules and microfilaments (Brodland and Gordon, 1990; Goldman et al., 1999).

Cells respond to their environment within a three dimensional tissue structure. The number of adhesive structures in a cell and its resulting cell polarity may change the way it will behave. For instance cells that are not polarized are more likely to undergo apoptosis (Zahir and Weaver, 2004; Ingber, 1999). Microgravity has effects on both cell shape and cytoskeleton (Gaboyard et al., 2002). Apoptosis may be affected when the cell cytoskeleton is disorganized. Abnormal patterning may either cause premature cell death or the lack of death at inappropriate times. (Zahir and Weaver, 2004).

Changes in cell architecture will cause changes in the way cells respond to their environment. Alterations in this architecture can be brought about by changes in the way microtubules and other cytoskeletal components behave in microgravity (Sytkowski, 2001). Changes in the position of cell structures such as mitochondria have been noted (Schatten et al., 2001). Changes observed in mitochondria clustering and the area around the nuclear envelope are likely to be caused by changes in the cytoskeleton (Schatten et al., 2001). Mitochondria clustering may cause an increase in the amount of glucose consumed by cells due to crowding. An increase in cell apoptosis is one significant consequence of the changes in cell structure and function that occur in microgravity (Schatten et al., 2001).

A cell must have polarity or it will undergo apoptosis (Zahir and Weaver, 2004; Flusberg et al., 2001). A cell must have a certain diameter and if it is stretched too flat it will undergo apoptosis and if it is too round it will undergo cell division (Ingber, 2003a).

A variety of cells have been tested under microgravity conditions. Table 1 lists some of them and the changes that were observed in microgravity.

Most cells appear to exhibit cytoskeleton changes when first exposed to microgravity (see Table 1). Some cell types recover their cytoskeleton after approximately three days but often show signs of changes in the nucleus and in cell shape. Microtubules and F-actin are affected when cells are first exposed to microgravity and cells often have increased apoptosis (Table 1). The reactions of cells to changing gravitational fields are dependent upon cell type and length of exposure (Table 1).

Convergent extension or intercalation (Belousov et al., 1999) is a process that causes the elongation of tissues (Belousov, 1999; Keller, 2002) and occurs during gastrulation. In microgravity, this process could be altered because the lamellipodiae formed during convergent extension require microtubules. Fillipodia may also be affected and, in fact, tend not to form in microgravity (Sundaresan et al., 2002). Thus, any situation where cell mobility or cell lamellipodiae are involved could be affected (Sundaresan et al., 2002; Vassy et al., 2003). The concept that microtubules support and stabilize lamellipodiae as they develop, is supported by Friedl and Brücker (2000) who found that lamellipodiae do not develop well when microtubules are disorganized. Cells that recover in microgravity have a different morphology than that in $1 \mathrm{G}$ (Uva et al., 2002). Calcium ion concentration will change polymerization of microtubules and other cell physiology may be 
altered in microgravity that will also affect this.

Changes in cell shape and movement as seen in microgravity could cause dysmorphology to occur during development. In breast cancer cells the cell cycle was also altered in microgravity (Vassy et al., 2003) with an increase in mitosis, which might be due to altered microtubules. Microfilament organization into stress fibers was lower. There was also a reduction in signal transductions from focal contacts. Intermediate filament network around the nucleus was looser after two days in microgravity and an alteration in chromatin structure was observed in interphase cells (Vassy et al., 2003). Breast cancer cells in general can be considered a growing and dividing cell line and the intermediate filament network is important in growing cells (Goldman et al., 1999). All cytoskeleton components are altered to some degree in microgravity so this can have far reaching consequences if the cells in question are embryo cells.

\section{Cytoskeleton}

When microtubules and other parts of the cytoskeleton do not behave in a normal fashion in cells, it can have a detrimental effect on individual cells and can have far reaching consequences when the cell is in an embryo.

The cytoskeleton forms the main structural component of cells and consists of interactions between microtubules, microfilaments, intermediate filaments and associated proteins (for a detailed review see Ingber, 2003a). Cell cytoskeleton therefore appears to be related to cell shape (Flusberg et al., 2001). Cell shape and cell cytoskeleton are altered in microgravity (Table 1).

Karyokinesis and cytokinesis are cellular processes that are dependent on microtubules. Microtubules form part of the centromere and are involved in spindle formation and cell membrane constriction during cell division (Maiato et al., 2004; Kline-Smith and Waczak, 2004). Furthermore, microtubules appear to have a role in moving cell organelles such as mitochondria, transporting intracellular vesicles and other cellular components inside the cell (Schatten et al., 2001; Glade et al., 2004; Maiato, 2004).

\section{Cytoskeleton abnormalities and genetic changes}

Cytoskeleton components are affected by microgravity as noted in Table 1. All of the cytoskeleton components; microtubules (MT), intermediate filaments (IF) and microfilaments (MF), become disorganized. The cytoskeleton does reorganize after a time in microgravity 20 to 72 hours, but does not always organize in the same configuration that it was in before (Sudareasan et al., 2002; Uva et al., 2002; Vassy et al., 2003; Sytowski and Davis, 2001; Gaboyard et al., 2002). In breast cancer cells the perinuclear cytokeratin network and chromatin structure were looser in microgravity (Vassy et al., 2003).

An experiment on human renal cells in space in a microgravity environment was monitored for gene expression. It was found that more than 1,632 genes changed expression including large changes in transcription factors (Hammond et al., 1999).

"The genes whose expression changed the most ... include adhesion molecules, apoptosis genes, cytoskeletal proteins, differentiation mediators, drug metabolizing proteins, select heatshock proteins, intracellular signaling proteins, receptors, transcriptions factors and elements of the electron transport chain". (Hammond et al., 2000).

\section{Gravitational fields and cytoskeleton organization}

Some work has been done on the effects that microgravity has on microtubules and there are noticeable differences in the organization of patterning in $1 \mathrm{G}$ earth gravity and in microgravity. In microgravity microtubules in vitro grow and organize in a homogenous or random pattern and in $1 \mathrm{G}$ they grow and spontaneously organize in a striped pattern Fig. 2B (Papaseit et al., 2000). The striped patterning is shown to consist of microtubule bundles oriented at 450 and 1350 from the horizontal in $1 \mathrm{G}$. Patterning occurs at different scales $0.5 \mathrm{~mm}$ wide stripes contain microtubule stripes that are separated by a distance of $100 \mu \mathrm{m}$ and contain stripes $20 \mu \mathrm{m}$ in width (Fig. 1). This specific organization does not occur in microgravity. Instead, microtubules in vitro have been shown to grow in a random fashion (i.e., in an isotropic pattern) as opposed to an organized pattern of organization that is created in earth's gravitational field (Papaseit et al., 2000) Fig. 2B.

Microtubules typically grow (polymerize) into long tubular polymers consisting of alpha- and beta-tubulin dimers bind together in a specific orientation. Microtubule polymerization is that of an out of equilibrium chemical reaction- diffusion process (Odde, 1997; Dogterom et al., 1995). The microtubules are continuously forming and disintegrating so that when a microtubule depolymerizes it leaves behind components to build another microtubule. The microtubule polymerization process is affected by gravity because there is more drift in the vertical direction than there is in lateral directions (Portet and Turzynski, 2003). The out of equilibrium chemical reaction undergoes a bifurcation, which creates the observed patterning of microtubule formation in $1 \mathrm{G}$ earth normal gravity.

Microfilaments link to the microtubule network in vivo to form a strong stable tensegrity structure (Ingber, 2003a,b). Microfilaments are altered in microgravity as well as microtubules (Gruener etal., 1994; Uva et al., 2002; Vassy et al., 2003; Plett et al., 2004). Microtubules may be stiffened against buckling via attachment to intermediate filaments in vivo (Brodland and Gordon 1990; Ingber et al., 2003a). Intermediate filaments are also formed in an out of equilibrium chemical reaction (Goldman et al., 1999) and can be similarly affected by changes in gravity.

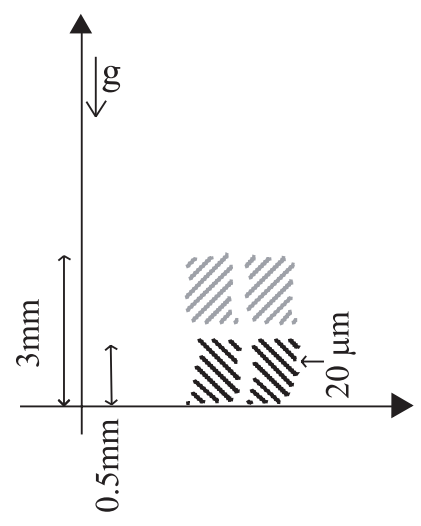

Fig. 1. Microtubule organization pattern in earth normal gravity (in vitro ). See Portet and Tuszynski, 2003; reproduced with permission. 
A

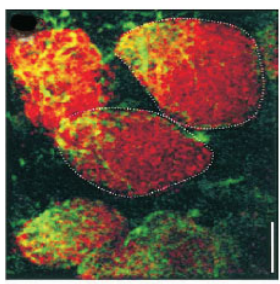

Cells in space micro-gravity

B

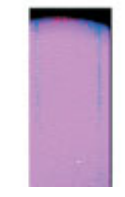

MT in Space

Microgravity
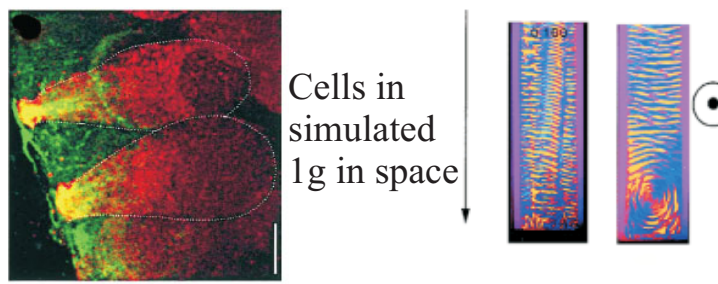

MT in

- simulated $1 \mathrm{~g}$ in space

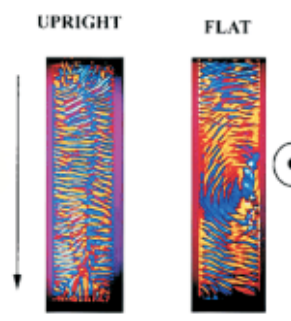

MT in simulated

- microgravity on earth

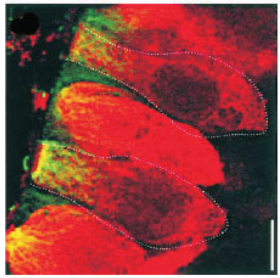

Cells in

earth

normal

gravity
C
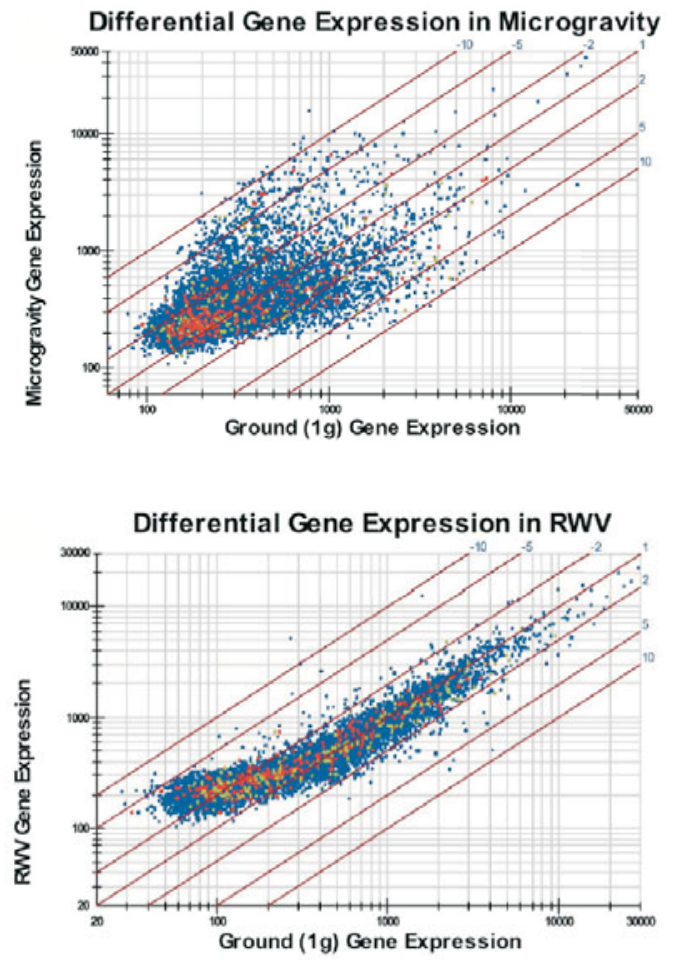

MT in centrifuge on earth

Fig. 2. Changes in (A) rat utricular cells, (B) microtubules and (C) gene expression under conditions of microgravity in space, simulated $1 G$ in

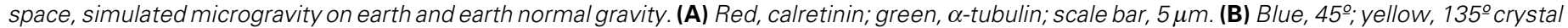
orientation. (C) Green, shear stress and heat shock proteins; red, transcription factors. (A) Gaboyard et al., 2002; (B) Papaseit et al., 2000; (C) Hammond et al., 2000. Reproduced with permission.

In cells, other vectors besides gravity, such as electric fields and Marangoni convection may affect the formation of microtubules (Ostrach, 1982; Egery, 2003; Glade and Tabony, 2005). The hypothesis is that microtubules form an electric field as they polymerize and if they do so they will be affected by each other's electric field which might cause, the patterning (Tuszynski et al., 1997). This may be why cells can still live and grow in microgravity. Microtubules are affected by magnetic fields and form patterns according to the direction of the field (Glade and Tabony, 2005). There are similarities between the effects on the grey crescent formation in amphibian eggs produced by UV radiation (Gerhart et al., 1981), the role of the grey crescent in axis formation and microgravity (Dorfman and Cherdantsev, 1977).

"In both cases the shape of the grey crescent fails to acquire its normal anisotropic shape, that of a crescent. As it is well know that microtubules and their assembly is the main target of UV radiation, it is reasonable to suppose that the same can be true for the effect of microgravity on cells". (V. Cherdantsev personal conversation).

\section{Physical effects of altered gravity}

There are many ways to produce altered gravity. One is to enter earth's orbit, which is a true microgravity, $1 \mathrm{G}$ can be produced in microgravity using a centrifuge, $1 \mathrm{G}$ is produced on earth, microgravity can be simulated on earth using a clinostat or rotating wall vessel and greater that $1 \mathrm{G}$ can be produced in a centrifuge. The three methods of producing $1 \mathrm{G}$ are not the same and do not produce the same effects.

A visual representation of some of the effects of microgravity compared to $1 G$ earth gravity is shown in Fig. 2.

There are many processes that are affected by microgravity and are altered due to changes in such phenomena the lack of buoyancy in microgravity. The following processes probably alter the way cells and tissues behave in microgravity.

\section{Reaction-diffusion processes}

Out of equilibrium chemical reactions are thought to be the main type of reactions that occur in and perhaps guide embryogenesis. This is because out of equilibrium reaction - diffusion 
chemical reactions create patterning that looks similar to biological patterns such as skin spots and branching (though looks can be deceiving: see angle fish patterns as discussed in Gordon, 1999). Belousov-Zhabatinski (BZ) reactions are a type of out of equilibrium reaction diffusion chemical process. BZ reactions in microgravity have been observed and it was found that the velocity of traveling waves is reduced (Fujieda et al., 2001). This effect is not as noticeable in gel type BZ reactions and is only noticeable when the gel surface is perpendicular to the original Gvector (Wiedemann et al., 2002). In an excitable biological medium, the brain, spreading depression (SD) waves can be created with a mechanical stimulus. These waves are normally seen throughout the central nervous system and are accompanied by hyper-excitation followed by a refractory period. In microgravity, spreading depression waves were created in retinal tissue of 7-14 day old chicken. In this excitable media it was found that wave propagation decreases under microgravity conditions (Wiedemann et al., 2002). The polymerization of microtubules is considered to be one of these reactions and as seen previously it is affected by microgravity (Papaseit et al., 2000). The change in these types of reactions will likely have effects on cells in microgravity.

\section{Molecular organization in collagen cells}

Other molecular organization is also altered in the microgravity environment. Results from the growth of collagen gels in microgravity and on earth show differences in their matrix morphology. Gravity is suggested to play a significant role in the morphology of such gels (Roedersheimer et al., 1997). This type of structuring is similar to crystal growth, which is also altered in microgravity. The microgravity environment does not produce convection currents and this alters the way processes work. In several space experiments by Claassen and Spooner liposome formation was altered in microgravity. In $1 \mathrm{G}$ the liposomes were smaller than 150 nanometers and in space microgravity liposomes were as large as 2000 nanometers. Convection currents are thought to play a role in the size of the liposomes (Claassen and Spooner, 1996).

\section{Ion channels in microgravity}

Ion channels have been shown to be altered by changes in gravity as well (Goldermann and Hanke, 2001). Ion channels in planar lipid bilayers were tested in microgravity and hypergravity. The polypeptide alamethicin, which forms voltage dependent ion pores was used in one experiment and the outer membrane proteins of Escherichia coli which contained porins were used in another experiment. A drop tower was used to produce the microgravity environment. It was found that microgravity decreased the open state of the porins. The alamethicin was unaffected by microgravity for a few hundreds of milliseconds and then the pore opening frequency is significantly reduced (Goldermann and Hanke, 2001). Surface tension driven flows dominate in microgravity while in $1 \mathrm{G}$ buoyancy dominates and this will have an effect at surfaces (Ostrach, 1982; Egery, 2003).

\section{Future research}

There have been observations of normal and abnormal development of embryos in microgravity. The causes of abnormal development can be difficult to discern. In order to explain the cellular mechanisms involved in the malformations of the embryo that may be induced in microgravity, many more studies of cell development during embryogenesis need to be conducted. Animals with known genetics, morphology and developmental outcomes should be used in experiments. The study of teratology could be used as a guide for such measurements. Embryonic processes such as cell sorting, intercalation and embryonic waves need to be studied in microgravity to see what changes occur. The orientation and growth of microtubules in microgravity is one process that profoundly affects living cells and therefore embryo development. Cytoskeleton formation and other processes are out of equilibrium reactions that can be affected by changes in the gravitational field. A summary of what happens to cells in microgravity does show changes in cell behavior that can be partially attributed to changes in the behavior of their cytoskeleton. We need to find out the causes for this if we are to live and reproduce in the space environment or in other altered gravity environments.

\section{Acknowledgements}

Thank you to Vladimir Cherdantsev for his critique and comments included in the paper and thank you to Stephanie Portet for her critique and advice. Also thank you to Nancy Young for proof reading the paper and to Richard Gordon and Sylviane Khane for editing and advice in writing the paper.

\section{References}

BELOUSSOV L.V., LOUCHINSKAIA N.N. and STEIN A.A. (1999) Tension-dependent collective cell movements in early gastrula ectoderm of Xenopus laevis embryos Dev Genes Evo/210: 92-104

BERGWERFF M., VERBERNE M.E., DERUITER M.C., POELMANN R.E. and GITTENBERGER-DE GROOT A.C. (1998) Neural crest cell contribution to the developing circulatory system, implications for vascular morphology? Circ Res. 82:221-131

BESOV N.V., SAVEL'EV S.V. and OIGENBICK E.A. (1992) Studies of Morphological Mechanisms of Calcium Metabolism Regulation: Experiments in Weightlessness, Rezul'taty issledovanii na biosputnikakh (Results of Studies aboard Biosatalites) 354-358, Nauka, Moscow

BJÖRKLUND N.K. and GORDON R. (1994) Surface contraction and expansion waves correlated with differentiation in axolotl embryos I. Prolegomenon and differentiation during invagination through the blastopore as shown by the fate map, Computers Chem 18: (3): 333-345

BJÖRKLUND, N.K., GORDON, R. and MARTIN, C.C. (1991). Defects due to compression of amphibian embryos at primary neural induction. In Proceedings of the 34th Annual Meeting, Ottawa: Canadian Federation of Biological Societies, p. 118.

BOONSTRA J. (1999) Growth factor-induced signal transduction in adherent mammalian cells is sensitive to gravity, The FASEB Journa/13:S35-S42

BRODLAND, G.W. and GORDON, R. (1990) Intermediate filaments may prevent buckling of compressively-loaded microtubules. J. Biomech. 112 (3): 319-321

CLAASSEN D.E. and SPOONER B.S. (1996) Liposome formation in microgravity. Advanced Space Research 17 (6/7):151-160

COLVIN G.A., LAMBERT J.F., CARLSON J.E., MCAULIFFE C.I., ABEDI M. and QUESENBERRY P.J. (2002) Rhythmicity of engraftment and altered cell cycle kinetics of cytokine-cultured murine marrow in simulated microgravity compared with static cultures, In Vitro Cell Dev. Biol. - Anima/38: 343-351

COPP A.J., GREENE N.D.E. and MURDOCH J.N. (2003) The Genetic Basis of Mammalian Neuralation, Nature 4: 784 -794

DOGTEROM, M., MAGGS, A.C. and LEIBLER, S. (1995) Diffusion and formation of microtubule asters: physical processes versus biochemical regulation. Proc Natl Acad Sci USA 92 (15): 6683-6688

DOOLAN E.J., GELDZILER B., STRANDE L., KAIN M. and HEWITT C. (1999) 
Effects of Microgravity on Growing Cultured Skin Constructs, Tissue Engineering 5:(6): 573-582

DORFMAN J. G. and CHERDANTSEV V. G. (1977) ÒStructure of morphogenetic movements of gastrulation in Anurans. I. Destabilization of ooplasmic segregation and cleavage by clinostat rotation.ó Ontogenez (Sov. J. Devel. Biol.) 8: 238-250; and II. Structure of gastrulation movements. Ibid. 8:251-262

EGERY I. (2003) Surface Tension Measurements in Microgravity and their Relevance to Marangoni Convection Chemphyschem 4: 329 - 333

FERREIRA M.C. and HILFER S.R. (1993) Calcium Regulation of Neural Fold Formation: Visualization of the Actin Cytoskeleton in Living Chick Embryos, Dev. Biol. 159: 427-440

FLINT R.W., GORDON R., MARTIN C.C. and BRODLAND G.W. (1990) Simulation of the inversion of amphibian eggs in a gravitational field using hollow glass spheres Proceedings of ESA Symposium, 11th ISDB Congress (ESA SP-1123): 81-83

FLUSBERG D. A., NUMAGUCHI Y. and INGBER D.E. (2001) Cooperative Control of Akt Phosphorylation, bcl-2 Expression and Apoptosis by Cytoskeletal Microfilaments and Microtubules in Capillary Endothelial Cells, Molecular Biology of the Cel/12: 3087-3094

FOTY R.A., PFLEGER C.M., FORGACS G. and STEINBERG M.S. (1996) Surface tensions of embryonic tissues predict their mutual envelopment behavior, Development 122:1811-1620

FRIEDL P. and BRÜCKER E.B (2000) The biology of cell locomotion within threedimensional extracellular matrix CMLS Cell Mol. Life Sci. 57: 41-64

FRITZSCH B. and BRUCE L.L. (1995) Utricular and saccular projections of fetal rats raised in normal and microgravity. American Society for Gravity and Space Biology Bulletin 9: 97

FUJIEDA S., MORI Y., NAKAZAWA A. and MOGAMI Y. (2001) Effect of Gravity Field on the nonequilibrium/ nonlinear chemical oscillation reactions, $A d v$. Space Res. 28:(4): 537-543

GABOYARD S, BLACHARD M.P., TRAVO B.T., VISO M., SANS A. and LEHOUELLEUR J. (2002) Weightlessness affects cytoskeleton of rat utricular hair cells during maturation in vitro, NeuroReport 13:(16):2139-2142

GERHART J., UBBELS G., BLACK S., HARA K. and KIRSCHNER M. (1981) A reinvestigation of the role of the grey crescent in axis formation in Xenopus laevis, Nature 292: 511-516

GILLAND E., MILLER A.L., KARPLUS E., BAKER R. and WEBB S.E. (1999) Imaging of multicellular large-scale rhythmic calcium waves during zebrafish gastrulation Proc. Natl. Acad. Sci. USA 96: 157-161

GLADE N., DEMONGEOT J. and TABONY J. (2004) Microtubule self-organisation by reaction-diffusion processes causes collective transport and organization of cellular particles, BMC Cell Biology 3:1-10

GLADE N. and TABONY J. (2005) Brief exposure to high magnetic fields determines microtubule self-organisation by reaction-diffusion processes Biophysical Chemistry 115:29-35

GOLDERMANN M. and HANKE W. (2001) Ion channel are sensitive to gravity changes Microgravity sci. technol. XIII/1: 35-38

GOLDMAN R.D., CHOU Y.H., PRAHLAD V. and YOON M. (1999) Intermediate filaments: dynamic processes regulating their assembly, motility and interactions with other cytoskeletal systems The FASEB Journa/13:S261-S265

GONG Y., MO C. and FRASER S. (2004) Planar cell polarity signaling controls cell division orientation during zebrafish gasturlation Nature 430: 689-693

GORDON R. (1999) The Hierarchical Genome and Differentiation Waves: Novel Unification of Development, Genetics and Evolution, World Scientific, Singapore

GORDON, R., GOEL N.S., STEINBERG M.S. and WISEMAN L.L. (1972) A rheological mechanism sufficient to explain the kinetics of cell sorting. J. Theor. Biol. 37: 43-73

GORDON, R., GOEL N.S., STEINBERG M.S. and WISEMAN L.L. (1975) A rheological mechanism sufficient to explain the kinetics of cell sorting. In: Mostow, G.D., Mathematical Mode/s for Cell Rearrangement, New Haven. Yale University Press, p. 196-230

GRIMM D., BAUER J., KOSSMEHL P., SHAKIBAEI M., SCHÖNBERGER J., PICKENHAHN H., SCHULZE-TANZIL G., VETTER R., EILLES C., PAUL M. and COGOLI A. (2002) Simulated microgravity alters differentiation and increases apoptosis in human follicular thyroid carcinoma cells FASEBJ. 16:604-
606

GRUENER R., ROBERTS R. and REISTETTER R. (1994) Reduced receptor aggregation and altered cytoskeleton in cultured myocytes after space-flight Biological Sciences in Space 8:(4):79-93

GUALANDRIS-PARISOT L., HUSSON D., FOULQUIER F., KAN P., DAVET J., AIMAR C., DOURNON C. and DUPRAT A.M. (2001) Pleurodeles walt, Amphibian, Urodele, is a suitable Biological Model for embryological and physiological space experiments on a vertebrate, Adv. Space Res. 28:(4):569-578

HAMMOND T.G., BENES E., O'REILLY K.C., WOLF D.A., LINNEHAN R.M., TAHER A., KAYSEN J.H., ALLEN P.L. and GOODWIN T.J., (2000) Mechanical culture conditions effect gene expression: gravity-induced changes on the space shuttle Physiol Genomics 3:(3): 163-173

HAN Z.B., ISHIZAKI K., NISHIZAWA K., KATO T., TODO T. and IKENAGA M. (1999) A genetic effect of altered gravity: mutations induced by simulated hypogravity and hypergravity in microsatellite sequences of human tumor cells, Mutation Research 426:1-10

HORNECK G. (1999) Impact of microgravity on radiobiological processes and efficiency of DNA repair Mutation Research/Fundamental andMolecularMechanisms of Mutagenesis 430:2:221-228

HUTSON M.R. and KIRBY M.L. (2003) Neural crest an cardiovascular development: a 20-year perspective Birth Defects Research (Part C) 69: 2-13

IJIRI, K., (1995) Medaka fish had the honor to perform the first successful vertebrate mating in space. Fish Biol. J. MEDAKA 7: 1-10

INGBER D.E. (2003a) Tensegrity I. Cell structure and hierarchical systems biology. J. Cell Science: 116:1157-1173

INGBER D.E. (2003b) Tensegrity II. How structural networks influence cellular information processing networks, J. Cell Sci. 116:1397-1408

INGBER D.E. (1999) How cells (might) sense gravity, FASEB Journa/13 Supplement: S3-S15

JENNINGS R. and SANTY P.A. (1989) Reproduction in the Space environment: Part II. Concerns for Human Reproduction Obstetrical and Gynecological Survey 45 (1): 7-17

KACENA M.A., TODD P. and LANDIS W.J. (2004) Osteoblasts subjected to spaceflight and simulated space shuttle launch conditions In Vitro Cel/Dev. Biol. -Anima/39:(10): 454-459

KELLER R.E. (2002) Shaping the vertebrate Body Plan by Polarized Embryonic Cell Movements Science 298: (5600): 1950-1954

KLINE-SMITH S.L. and WACZAK C.E. (2004) Mitotic Spindle Assembly and Chromosome Segregation: Refocusing on Microtubule Dynamics Mol. Cell 15:317-327

KOJIMA Y., SASAKI S., KUBOTA Y., IKEUCHI T., HAYASHI Y. and KOHRI K. (2000) Effects of simulated microgravity on mammalian fertilization and preimplantation embryonic development in vitro Fertility and Sterility, Dev. 74:(6): 1142-1147

KOMAZAKI S. (2004) Gravitational Effects on Apoptosis of Presumptive Ectodermal Cells of Amphibian Embryo, J. Exp. Zoology 301A:204-211

LAWSON A. and ERSON H. and SCHOENWOLF G.C. (2001) Cellular mechanisms of neural fold formation and morphogenesis in the chick embryo The Anatomical Record 262:(2): 153-168

LEWIS M.L., REYNOLDS J.L., CUBANO L.A., HUTTON J.P., LAWLESS B.D. and PIEPMETER E.H. (1998) Spaceflight alters microtubules and increases apoptosis in human lymphocytes (Jurkat) FASEB J. 12:1007-1018

LI X.G. and WANG G.Z. (1992) The effects of microgravity on the character of progeny of Drosophila melangaster, Microgravity Sci. Techno/2: 94-97

MAIATO H., SAMPAIO P. and SUNKLE C.E. (2004) Microtubule-associated proteins and their essential roles during mitosis Int. Review Cytol. 241: 53-153

MARCO R., BENGURIA A., SÁNCHEZ J. and DE JUAN E. (1996) Effects of the Space Environment on Drosophila melegaster development. Implications of the IML-2 experiment J. Biotechnology 4:179-189

MARIN O. and RUBENSTEIN J.L. R. Cell migration in the forebrain (2003) Ann. Rev. Neuroscience 26:441-483

MAURUS D. and KUHL M. (2004) Getting an embryo into shape, BioEssays 26:1272-1275

NEFF A.W., WAKAHARA M., JURAND A. and MALACINSKI G.M. (1984) Experi- 
mental analyses of cytoplasmic rearrangements which follow fertilization and accompany symmetrization of inverted Xenopuseggs. J. Embryol. Exp. Morph. 80:197-224

NEFF A. W., YOKOTA H., CHUNG H. M., WAKAHARA M. and MALACINSKI G.M. (1993) Early Amphibian (Anuran) Morphogenesis is Sensitive to Novel Gravitational Fields Dev. Biol. 155:270-274

NIEUWKOOP, P.D., BJORKLUND, N.K. and GORDON, R. (1996) Surface contraction and expansion waves correlated with differentiation in axolotl embryos. II. In contrast to urodeles, the anuran Xenopus laevis does not show furrowing surface contraction waves. Int. J. Dev. Biol. 40: 661-664

ODDE, D.J. (1997) Estimation of the diffusion-limited rate of microtubule assembly. Biophys $J 73$ (1): 88-96

OSTRACH S. (1982) Low-Gravity Fluid Flows Ann, Rev. Fluid Mech. 14:313-345

ORBAN J.I., PIERT S.J., GURYEVA T.S. and HESTER P.Y. (1999) Calcium utilization by quail embryos during activities preceding space flight and during embryogenesis in microgravity aboard the orbital space station, MIR Journal of Gravitational Physiology 6:(2):33-41

PAPASEIT C., POCHON N. and TABONY J. (2000) Microtubule self-organization is gravity-dependent Proc. Natl. Acad. Sci. USA 8:(97):(15): 8364-8368

PLETT P.A., ABONOUR R., FRANKOVITZ S.M. and ORSCHELL C.M. (2004) Impact of modeled microgravity on migration, diffrentiation and cell cycle control of primitive human hematopoietic progenitor cells Experimental Hematology32: 773-781

PORTET S. and TUSZYNSKI J.A. (2003) Models of spatial and orientational selforganization of microtubules under the influence of gravitational fields Physical Review E. 68, 021903- (1-9)

ROEDERSHEIMER M.T., BATEMAN T.A. and SIMSKE S.J. (1997) Effect of gravity and diffusion interface proximity on the morphology of collagen gels $\mathrm{J}$ Biomed Mater Res 37: 276-281

RONCA A.E. and ALBERTS J.R. (2000) Effects of prenatal space flight on vestibular responses in neonatal rats $J$ Applied Physiology 89: 2318-2324

RONCA A.E. (2003) Studies Toward Birth and Early Mammalian Development in Space Adv. Space Res. 32: (8):1483-1499

SAKAR D., NAGAYA T., KOGA K. and SEO H. (1999) Culture in Vector-averaged Gravity Environment in a Clinostat Results in Detachment of Osteoblastic ROS 17/2.8 Cells Environmental Medicine 43: (1):22-24

SALMON W.C., ADAMS M.C. and WATERMAN-STORER C.L. (2002) Dualwavelength fluorescent speckle microscopy reveals coupling of microtubule and actin movements in migrating cells $\mathrm{J}$. Cel/ Bio/July 8, 158: (1):31-37

SAUSEDO R.A., SMITH J.L. and SCHOENWOLF G.C. (1997) Role of Nonrandomly Oriented Cell Division in Shaping and Bending of the Neural Plate J. Comp. Neurol. May 19, 381:(4): 473-488

SCHATTEN H., CHAKRABARTI A., TAYLOR M., SOMMER L., LEVINE H. ANDERSON K., RUNCO M. and KEMP R. (1999) Effects of spaceflight conditions on fertilizaion and embryogenesis in the sea urchin Lytechinnus pictus Cel/ Biology Internationa/23: (6): 407-415

SCHATTEN H, LEWIS M.L. and CHAKRABARI A. (2001) Spaceflight and clinorotation cause cytoskeleton and mitochondrea changes and increases in apoptosis in cultured cells, Acta Astronautica 49: (3-10) :399-418

SEROVA L.V., DENISOVA L.A., APANASENKO Z.I., KUZNETOSOVA M.A. and MEIZEROV E.S. (1982) Reproductive function of the male rat after a flight on the Kosmos-1129 biosatellite Kosm. Biol. Aciakosm. Med. Sept-Oct. 16(5): 6265

SHEN H.L., CHEN Y. and SUN T. (1998) Effects of clinorotation on cytosolic free calcium level in embryonic chick brain cells Space Medicine and Medical Engineering (in Chinese), Dec., 11:(6): 447-450

SHENKER E. and FORKHEIM K., (1998) Mammalian mice embryo early development in weightlessness environment on STS 80 space flight. Israel Aerospace Medicine Institute Report

SUNDARESAN, A., RISIN, D. and PELLIS N.R. (2002) Loss of signal transduction and inhibition of lymphocyte locomotion in a ground-based model of microgravity In Vitro Cell. Dev. Biol. - Anima/38: (2): 118-122

SYTKOWSKI A. J. and DAVIS K.L. (2001) Erythroid Cell Growth and Differentiation in Vitro in the Simulated Microgravity Environment of the NASA Rotation Wall Vessel Bioreactor In Vitro Cell Dev. Biol. - Anima/37:79-83

TOU J., RONCA A., GRINDELAND R. and WADE C. (2002) Models to Study Gravitational Biology of Mammalian Reproduction Biology. Reproduction 67: 1681-1687

TUSZYNSKI J.A., TRPISOVÁ B., SEPT D. and BROWN J.A. (1997) Selected Physical Issues in the Structure and Function of Microbubules J. Structural Biology 118:94-106

UBBELS G.A. (1997) Fertilisation and development of Xenopus eggs on sounding rockets and clinostat ESA sp1206: 25-36

UVA B.M., MASINI M.A., STURLA M., PRATO P., PASSALACQUA M., GIULIANI M., TAGLIAFIERRO G. and STROLLO F. (2002) Clinoration-induced weightlessness influences the cytoskeleton of glial cells in culture Brain Res. 934:132139

VASSY J., PORTET S., BEIL M., MILLOT G., FAUVEL-LAFÈVE F., GASSET G. and SCHOEVAERT D. (2003) Weightlessness Acts on Human Breast Cancer Cell Line MCF-7 Adv. Space Res 32: (8):1595-1603

VERNÓS I., GONZÁLEZ-JURADO J., CALLEJA M. and MARCO R. (1989) Microgravity effects on the oogenesis and development of embryos of Drosophila melanogasterlaid in the spaceshuttle during the Biorack experiment (ESA) (1989) Int. J. Dev. Biol. 33: 213-226

WEBB S.E. and MILLER A.L. (2003) Calcium Signaling During Embryonic Development Reviews Molecular Cell Biology Nature 4:539-551

WEINSD. and OLSON W., Does Microgravity affect development of head cartilages in Xenopus? University of North lowa, http://www.bio.uni.edu/students/2004/gaul-rodriguez.html

WIEDEMANN M., FERNANDES DE LEIMA V. M. and HANKE W. (2002) Gravity dependence of waves in the retinal spreading depression and in gel type Belousov-Zhabotinsky systems Phys. Chem. Chem Phys. 4:1370-1373

ZAHIR N. and WEAVER V.M. (2004) Death in the third dimension Current Opinion in Genetics and Development 14:71-80

ZOLESSI F.R. and ARRUTI C. (2001) Apical accumulation of MARKS in neural plate cells during neuralation in the chick embryo Dev. Biol. 1:(1):7-15 